\title{
Ekspansi Geografis dan Perampasan Lahan: Sisi Lain Pembangunan Yogyakarta International Airport
}

\section{Luthfian Haekal}

Social Movement Institute (SMI) Yogyakarta

\begin{abstract}
:
Pembangunan bandara di Kulon Progo, Indonesia menggerus lahan pertanian masyarakat secara masif. Penggerusan ini diakibatkan oleh dorongan mengonversi modal ke dalam bentuk baru guna memberikan ruang akumulasi kapital yang lebih banyak menghasilkan uang. Dengan beragam cara dan desain kebijakan, ruang-ruang ini dikondisikan guna menjadi instrumen akumulasi kapital yang efektif yang mempertemukan berbagai sektor bisnis, termasuk partiwisata di Yogyakarta. Tulisan ini mendiskusikan ekspansi ruang yang terbentuk melalui pembangunan bandara, dan bagaimana ruang didefinisikan sebagai akumulasi kapital menggunakan teori yang diajukan David Harvey and Henri Lefebvre. Melalui analisis ruang, artikel ini menjelaskan efek infrastruktur terhadap marjinalisais manusia melalui proyeksi keruangan yang dibuat negara dan korporasi. Selanjutnya, ekspansi keruangan imajiner ini berekspansi pada ranah ketenaga-kerjaan yang menjadi syarat beroperasinya produksi supaya akumulasi kapital mewujud.
\end{abstract}

\section{Keywords:}

YIA; displacement capital; land grabbing; expansion of space

\section{Pendahuluan}

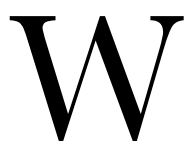

aktu itu, 19 Juli 2018. Wagirah masih mengenakan mukena merah mudanya dalam posisi sujud menghadang aparat keamanan yang berjejer-jejer. Tidak punya rasa takut, ia menjadi representasi perlawanan. Melawan kekuatan absolut Sultan, Negara, dan Korporasi yang mengancam hidupnya. Ia diangkut paksa. Tidak hanya diangkut, tetapi juga diseret. Polisi memegangi kedua kakinya seakan-akan hendak dilempar agar tidak menghalangi proses pengosongan lahan. Tidak kuasa melawan lagi, ia hanya bisa menangis. Suara tangisannya tidak terdengar oleh aparat keamanan. Mereka semua membisu dan tetap melakukan pengosongan lahan untuk keperluan pembangunan bandara Yogyakarta International Airport (YIA). Sujudnya Wagirah adalah sujud seorang rakyat di atas tanah yang kehilangan akses tanahnya. 
Proses pengosongan lahan dengan penuh paksaan bukan pertama kalinya dilakukan oleh PT Angkasa Pura I. Pada tanggal 28 Juni 2018, proses pengosongan lahan juga penuh kekerasan. Meskipun, klaim dari PT Angkasa Pura I yang dijadikan sasaran adalah tanaman palawija (Cahyono, 2018). Sekitar 500 personel keamanan dikerahkan untuk mengamankan proses pengosongan lahan. Mereka terdiri dari gabungan Kepolisian, TNI, dan SatPol PP.

Warga memeluk tanamannya yang masih bertengger di tanah. Dari tanaman cabai hingga pohon kelapa mereka peluk, karena tanaman mereka yang menjadi sasaran pengosongan lahan. "Salah pohon saya apa?" teriak Wagirah. Ia pun menaiki bibir ekskavator yang berfungsi untuk meluluhlantakkan lahannya. Ustaz Sofyan yang berada dalam kerumunan juga mengabadikan momen tersebut lewat memori di otaknya. "Allahu Akbar. La ilaha Illallah," teriak Ustaz Sofyan dengan isak tangisnya tak kuasa melihat tanaman yang ia tanam digilas proyek bandara. Ia diseret dua polisi. Tubuhnya dibawa kedua polisi tersebut. Kakinya lemas tak mampu melawan kekuatan polisi yang menyeretnya. Kekuatannya habis setelah melihat tanamannya mati.

Setelah Wagirah diusir dari bibir ekskavator, ia dikelilingi oleh puluhan polisi wanita. Polisi-polisi wanita tersebut saling bergandeng tangan membentuk lingkaran yang ditengahnya berisi Wagirah. "Penjara hidup" dibuat untuk mengusir Wagirah agar berhenti menghampiri aparat keamanan dan petugas yang sedang mengosongkan lahan. Di balik "penjara hidup" itu, Wagirah menyaksikan sendiri tanaman yang sudah ia tanami dilindas dan dikeruk oleh ekskavator. Gampang sekali ekskavator itu membalik bumi. "Dinggo anak putuku. Saiki kok tok rusak. Aku ra trimo. Wasiat e simbokku ora entuk didol (untuk anak cucu saya. Sekarang kenapa malah kamu rusak. Aku tidak terima. Wasiat dari ibuku tidak boleh dijual)," teriak Wagirah dibarengi dengan isak tangisnya. Ia kemudian mendekati salah satu polisi wanita yang menjadi "penjara hidup", lalu berkata, "Aku arep mangan opo? Mangan awan? (aku mau makan apa? Makan awan?)".

Bagi masyarakat Jawa, tanah sama saja dengan kehormatan. "Sadumuk bathuk sanyari bumi ditohi pati jiwa" itulah istilah yang biasa dipakai untuk penghormatan terhadap tanah bagi masyarakat Jawa. Kalimat itu berisikan tentang sejengkal tanah yang akan dibela mati-matian oleh masyarakat Jawa, karena tanah adalah harga diri mereka.

Wagirah atau pun Sofyan hanyalah salah dua contoh rakyat yang kehilangan akses tanahnya akibat perampasan lahan guna pembangunan YIA. Perampasan tanah itu terkait dengan Masterplan Percepatan dan Perluasan Pembangunan Ekonomi Indonesia (MP3EI) masa Susilo Bambang Yudhoyono. Dalam proyek tersebut, pembangunan bandara internasional di Yogyakarta merupakan hal yang wajib untuk dilaksanakan untuk menghubungkan antar koridor ekonomi (Kemendag, 2012). Bandara tersebut menjadi salah satu proyek pembangunan pemerintah yang diklaim mampu meningkatkan laju pariwisata. Ia juga menjadi titik kritis pembangunan di Yogyakarta, karena akan menentukan pembangunan-pembangunan berikutnya. Akan tetapi, sekitar 
634,5 hektare lahan produktif di pesisir Kulonprogo dan kurang lebih sebanyak 2.465 warga harus dikorbankan untuk pembangunan YIA.

Bagi warga sekitar yang hidup dari lahan pertanian, mereka sudah merasa berkecukupan. "Sesak dada saya kalau memikirkan rencana dibangunnya bandara. Masak pemerintah mau membasmi petani begitu saja," tutur Wagirah. Bagi mereka, tanah adalah satu-satunya ranah untuk "subsistensi". Mereka menyulap lahan-lahan dekat pantai untuk bisa ditanami dengan berbagai jenis tanaman. Misalnya, Padi, Gambas, Cabai, Terong, dan lainnya. selama 35 tahun terakhir (1980-2015), kawasan pesisir selatan Kulon Progo telah berkembang menjadi kawasan pertanian produktif. Dengan adanya YIA, akan mengancam berkurangnya 60 ton gambas perhektar/tahun, 180 ton melon perhektar/tahun, 90 ton terong perhektar/tahun, 90 ton semangka perhektar/tahun, dan 30 ton cabai perhektar/tahun.

Rencananya, tidak hanya bandara yang akan terbangun. Namun, ia juga akan membangun kota bandara sebagai sentralitas akumulasi kapital yang akan menentukan roda perekonomian di Yogyakarta. Harapannya, ia bisa meningkatkan perekonomian sektor informal di masyarakat. Dengan demikian mendongkrak angka kesejahteraan di Kulon Progo.

Bagi Yogyakarta, terdapat sepuluh keuntungan yang dialami ketika bandara terbangun (DIY, 2017). Pertama, mengakselerasi terwujudnya visi DIY sebagai daerah tujuan wisata terkemuka di Asia Tenggara tahun 2025. Kedua, membuka transaksi perdagangan, wisata, dan investasi menuju peradaban baru abad ke-21. Ketiga, mendongkrak jumlah wisatawan mancanegara. Keempat, membuka banyak lapangan kerja. Kelima, membuka lapangan usaha baru. Keenam, menarik minat banyak investor. Ketujuh, mempercepat lalu lintas penumpang, barang, dan jasa. Kedelapan, meningkatkan jumlah dan lama tinggal kunjungan ke daerah tujuan wisata. Kesembilan, meningkatkan pendapatan daerah. Kesepuluh, memberi efek domino pengembangan pertumbuhan ekonomi yang tinggi.

Sebagai detonator perekonomian, pembangunan burung besi di Kulonprogo menjadi wajib, karena kapasitas Bandara Adisutjipto sudah tidak mencukupi lagi. Kapasitas terminal dirancang untuk menampung 1,2 juta penumpang per tahun. Namun, pada akhir tahun 2015 jumlah penumpang sudah naik menjadi 6,3 juta (Dephub, 2016). Selain itu, kapasitas area parkir pesawat hanya mampu menampung delapan pesawat terbang dan mengakibatkan keterlambatan penerbangan. Selain itu, bagi PT. Angkasa Pura I, Bandara Adisutjipto sudah tidak bisa dilebarkan lagi karena keterbatasan lahan dan sudah terlalu padat -selain "konflik" dengan TNI AU . Sebagai salah satu provinsi yang diniatkan untuk pariwisata, hal tersebut merugikan Yogyakarta. Karena, Yogyakarta tidak akan bisa memutar kapital tanpa adanya pariwisata. 
Pembangunan burung besi niatnya digunakan untuk mengoptimalkan sektorsektor pariwisata yang ada di DIY. Beberapa tempat pariwisata yang ingin dihubungkan adalah Pantai Siung, Pantai Pok Tunggal, Pantai Sundak, Pantai Baron, dan Pantai Glagah (Dephub, 2016). Tidak hanya pantai saja, tetapi ia juga untuk meningkatkan destinasi ke Gua Pindul, Gua Kalisuci, Gua Rancang Kencono, Gua Kiskendo, Gua Jomblang, dan lainnya (Dephub, 2016).

Oleh karenanya bandara diperlukan untuk menghubungkan sektor-sektor pariwisata sembari mengakumulasikan kapital dan membayangkan ruang yang akan dibentuknya. Dalam pariwisata, ekploitasi atas sumber daya alam dimaknai sebagai penciptaan "ruang-ruang konkrit" yang sesuai dengan ruang yang ingin direpresentasikannya (Fletcher \& Neves, 2012). "Ruang" disini dimaksudkan untuk menunjukkan pembentukan yang erat kaitannya dengan perkembangan mode produksi suatu masyarakat "modern", di mana produksi pengetahuan mengenai ruang merupakan refleksi atas relasi keduanya (Pamungkas, 2016).

Konsekuensinya, pembentukan dan "imajinasi" ruang menyebabkan hegemoni pengetahuan terus direproduksi untuk mempertahankan konsep ruang sebagai suatu hasrat untuk "memamerkan diri". Pembayangan atas representasi ruang yang diciptakan oleh negara dan PT. Angkasa Pura I adalah ruang representasi "modern" yang dipicu dengan adanya Bandara dengan berbagai pengetahuan yang direproduksinya. Hasrat "memamerkan diri" yang dibentuk oleh PT. Angkasa Pura I adalah modernitas yang dipicu oleh bandara memicu berbagai pertumbuhan ekonomi, pertumbuhan industri, kota bandara tempat berputarnya kapital, ruang-ruang hijau dan lainnya. Serta, Green city yang diniatkan diterapkan di Wates merupakan konsekuensi logis hasrat "memamerkan diri". Ia tidak hanya sebatas penciptaan "ruang" dalam bentuk fisik, namun juga berbagai macam perilaku di atasnya. Kota sebagai ruang adalah sebagai sebuah cerminan yang hidup di dalamnya.

Dalam perkembangan ekonomi neoliberal, bandara menjadi salah satu penunjang untuk menghubungkan sektor-sektor industrial sembari melakukan eksploitasi terhadap alam (Rachman, 2017). Pembangunan infrastruktur memiliki fungsi khusus melayani komoditas untuk bersirkulasi, khususnya dengan jalur darat, laut, atau pun udara. Komoditas ditransportasikan dari satu tempat ke tempat lainnya hingga ke konsumen. Pariwisata telah menjadi salah satu modus untuk mengakumulasikan kapital sembari menghubungkan koridor-koridor ekonomi antar negara. Globalisasi Neoliberal tidak ragu lagi telah mendorong proses pengurangan jumlah petani yang memiliki akses langsung ke tanah (Habibi, 2016).

Oleh karenanya, artikel jurnal ini mendiskusikan tentang perluasan akumulasi kapital pasca terbangunnya bandara YIA di Yogyakarta. Tentunya akumulasi kapital itu diikuti oleh eksklusi masyarakat dari tanahnya -atau bisa dibahassakan akumulasi primitif. 
Melalui pembacaaan David Harvey mengenai sirkuit kapital, artikel ini berusaha mengupas ekpansi geografis yang menjadi keniscayaan pasca terbangunnya YIA.

\section{Konstruksi Teori}

Mengikuti analisis Karl Marx tentang keadaan di Inggris, banyak ilmuwan telah melihat akumulasi primitif - "proses historis pencerabutan subjek dari alat produksinya" - sebagai proses awal mula kapitalisme di Eropa atau sebagai inti transisi kapitalisme di Inggris (Levien, 2000). Dalam akumulasi primitif, Marx menggambarkan transformasi dari feodalisme ke kapitalisme yang terjadi di Eropa selama abad kelima belas sampai abad kedelapan belas. Istilah tersebut merujuk pada sebuah proses di mana orang didorong untuk meninggalkan tanah mereka untuk mencari pekerjaan di pabrik atau kapal (Holden, Nadeau, \& Jacobson, 2011).

Pada penggambaran masa tersebut, petani-petani yang tidak mempunyai tanah selama berabad-abad terlibat dalam hubungan timbal balik dengan tuan tanah tidak dapat mengandalkan relasi tersebut. Para petani yang tidak mempunyai tanah dipaksa untuk menjadi pekerja-pekerja murah di pabrik dan tuan-tuan tanah dipaksa untuk menjual tanahnya (Holden et al., 2011). Dalam ilustrasi tersebut, Marx sangat ingin menunjukkan bahwa "penaklukan, perbudakan, perampokan, pembunuhan, singkatnya, memainkan bagian terbesar "dalam proses tersebut. Konsep Marx tentang akumulasi primitif mengidentifikasikan kolonialisme, eksploitasi dan pembunuhan masyarakat adat, perbudakan, dan mekanisme kredit sebagai "momen utama" dalam proses akumulasi primitif yang memberikan surplus untuk pengembangan produksi kapitalis di Eropa

Harvey (2005)dalam bukunya "New Imperialism" kemudian mengkontekskan Marx dengan apa yang terjadi hari ini. Harvey menjelaskan tentang bagaimana neoliberalisme berpengaruh terhadap keterpinggiran masyarakat dalam ranah-ranah kota. Sederhananya, ia menceritakan ketertindasan rakyat oleh proyek-proyek neoliberal. Harvey membaginya dalam tiga sirkuit kapital; sirkuit primer, sirkuit sekunder, dan sirkuit tersier. Ketiganya menunjukkan "kemampuan" akumulasi dari proyek-proyek neoliberal. Harvey menjelaskan sirkuit-sirkuit kapital sebagai berikut: (1) sirkuit primer adalah ranah produksi dan konsumsi langsung; (2) sirkuit sekunder sebagai ranah pembentukan kapital dan konsumsi tetap; dan (3) sirkuit tersier yaitu ranah belanja-belanja sosial dan riset serta pengembangan (Harvey, 2005).

Dalam sirkuit sekunder arus kapital terbagi menjadi kapital tetap untuk produksi (pabrik dan perlengkapan, kapasitas penghasil listrik, jaringan rel kereta api, pelabuhan, dsb.) dan penciptaan dana konsumsi (misalnya, perumahan). Secara luas, kapital tertentu dalam sirkuit sekunder ditanamkan dalam bentuk tanah dan menjadi aset-aset bank dan menempati tempat yang dibangun untuk produksi dan konsumsi (kawasan industri, jaringan transportasi, perumahan, rumah sakit, sekolah). Investasi tersebut bisa menyerap sejumlah besar kapital dan tenaga kerja, terutama ketika ekspansi geografis terjadi (perpindahan penduduk atau pun ekpansi teritorial). Arus menuju sirkuit tersier - 
investasi jangka panjang dalam infrastruktur sosial - terbagi dalam investasi untuk riset dan pengembangan atau pelatihan keterampilan yang secara langsung memberikan umpan balik kepada produksi, dan investasi yang berorientasi pada peningkatan kondisi sosial dari masyarakat (misalnya pendidikan, pelayanan kesehatan, pelatihan-pelatihan menaikkan labor power).

Cara-cara seperti produksi ruang, pembukaan kompleks sumber daya baru dan murah, pembukaan kawasan baru sebagai ruang akumulasi kapital yang dinamis, dan penetrasi formasi sosial yang telah ada menjadi cara untuk penyerapan surplus tenaga kerja. Namun, ekspansi dan rekonstruksi geografis semacam itu mengancam nilai-nilai yang telah terfiksasi -ada- dalam ruang yang melekat pada tanah. Tak hanya tanah, namun sesuatu yang dianggap memiliki nilai pembentuk kebudayaan suatu masyarakat. Maka tak ayal apabila terjadi perubahan pola-pola relasi yang sebelumnya telah ada. Meski demikian, penolakan penetrasi-penetrasi kapital memungkinkan untuk menjaga nilai-nilai yang terfiksasi yang melekat pada tanah atau benda lain yang dilekatkan nilai pembentuk "kebudayaan".

Sederhananya, Harvey (1978) menggariskan dua solusi penyerapan surplus melalui displacement capital: 1) displacement spasial, dimana kapital diberdayakan untuk membuka infrastruktur kapitalisme di lokasi lain; dan 2) displacement temporal, dimana kapital dipergunakan sebagai investasi dalam proyek-proyek fisik dan sosial berjangka panjang, yang hasilnya hanya bisa diraup di masa depan. Maka, dengan adanya YIA ini sebagai salah satu unsur sirkuit kapital dalam ruang sirkuit yang lain akan memungkinkan penetrasi-penetrasi yang telah dijelaskan di atas. Mulai dari produksi ruang, pembukaan kompleks tenaga kerja murah, pembukaan kawasan baru sebagai ruang akumulasi kapital yang dinamis - bisa menjadi ruang bagi tenaga kerja yang belum terserap dan diombangambingkan-, atau pun penetrasi formasi sosial yang lain. Pembukaan-pembukaan ruang tersebut akan menguras banyak lahan dan tentu saja penggusuran akan terjadi.

Bandara YIA merupakan infrastruktur yang menentukan dalam menggenjot mata rantai industri di Yogyakarta. Namun, di beberapa daerah seperti Yogyakarta dan Sleman, terjadi konflik penolakan hotel dan apartemen, karena menimbulkan persoalan sosial dan lingkungan. Persoalan lingkungan sudah jelas dengan berbagai kampanye "Jogja Asat". Ketersediaan air tanah warga yang berkurang, bahkan hilang karena massifnya pembangunan Hotel dan Mall di Yogyakarta. Bangunan-bangunan tersebut merampas hak warga atas air.

Ruang agraris direorganisasi, diubah berganti dari sumber daya alam menjadi komoditas global. Ekspansi sistem produksi yang meluas memerlukan reorganisasi ruang yang khusus agar sistem produksi bisa melias secara geografis. Reorganisasi ruang tersebut memaksa kehidupan masyarakat agraris berubah dari keadaan kampung, ladang, dan sawah menjadi kawasan industri. Akhirnya, reorganisasi ruang tersebut menyingkirkan dan meminggirkan rakyat agraris dari tanah dan ruang kehidupannya. 
Idealnya, pembangunan infrastruktur memang diperlukan untuk menggerek roda perekonomian negeri. Namun, dibalik narasinya yang menggiurkan-mendongkrak kesejahteraan, mendongkrak PDB, dan narasi lainnya- tersimpan cerita duka bagi petani dan rakyat kecil. Sementara, kaum elite dan pengembang sibuk untuk bagi-bagi keuntungan lewat akumulasi kapital. Baik akumulasi kapital "utama" maupun akumulasi kapital "alternatif".

Sebagai displacement spasial, YIA dibangun di luar area pembangunan utama Yogyakarta. Dan, displacement temporal, YIA berperan sebagai investasi berjangka panjang. Melalui pembangunan YIA, surplus kapital yang "diam" dapat diputar ulang dalam bentuk investasi eksternal, sehingga menghilangkan risiko devaluasi surplus dan memungkinkan akumulasi kapital di Yogyakarta untuk terus berjalan. Oleh karenanya, pembangunan YIA wajib dilakukan meski mengindahkan aspek-aspek ekologis.

Pada waktu yang lain, Henri Lefebvre mengartikan "ruang” untuk menganalisis keruangan. Dalam memproduksi ruang, tindakan-tindakan sosial itulah yang memberikan "makna” pada ruang. Sementara, representasi ruang yang dimaksud adalah pola hubungan produksi dan tatanan yang bertujuan memaksakan suatu pola hubungan tertentu atas "pemakaian" suatu ruang. Sementara, Ruang Representasional merupakan ruang yang secara nyata "hidup" dengan berbagai bentuk pencitraan dan simbol. Representasi ruang PT. Angkasa Pura I diruntuhkan oleh ruang representasional yang dibentuk oleh masyarakat sekitar dengan berbagai simbol-simbol perlawanan. Ruang kemudian menjadi hal yang sangat bergantung pada kelompok-kelompok dan relasi sosial yang membentuknya.

Dalam mengerjakan artikel ini, penulis melakukan penelitian dengan menggunakan metode pengumpulan data dengan menggunakan observasi. Pengumpulan data observasi lewat keikutsertaan melalui beberapa kegiatan penolakan pembangunan YIA oleh berbagai subjek. Melalui metode observasi, penelitian ini menggunakan data lewat obrolan dengan warga sekitar di Temon, Kulon Progo. Observasi dimulai pada pertengahan 2017 sampai pertengahan 2018. Sementara, data sekunder didapat dari data-data liputan maupun data presentasi publik PT Angkasa Pura I yang diunggah di internet. Data liputan berasal dari media arus utama maupun pers mahasiswa (persma). Alasan penggunaan data liputan persma, karena persma juga turut hadir dalam kegiatan keseharian masyarakat. Mereka membangun hubungan dengan warga penolak.

Saya tidak mewawancarai Pemda atau secara luas aktor dari pemerintah maupun dari sektor swasta. Hal ini karena relasi kuasa yang sangat timpang antara warga penolak dengan negara dan swasta. Karena relasi kuasa yang timpang itu, saya ingin memberikan ruang yang lebih luas kepada warga penolak. Apalagi, gerakan penolakan bandara yang selama ini telah menjadi kekuatan warga telah dipukul mundur oleh negara dengan berbagai aparatur kekerasannya. 


\section{Penetrasi Tenaga Kerja}

Pada bagian pembahasan akan dititikberatkan pada dua hal, yaitu penetrasi tenaga kerja serta arus barang dan manusia. Melalui David Harvey artikel ini mengalisis terhadap dua hal tersebut. Penjelasan Harvey mengenai displacement capital akan menguatkan pembahasan mengenai pembagian sirkuit kapital dengan kontekstualisasi pengorganisiran keruangan untuk YIA.

Untuk gambaran lebih besar bagaimana Harvey digunakan untuk kontekstualisasi, saya mengutip Sjamsinarsi (2019):

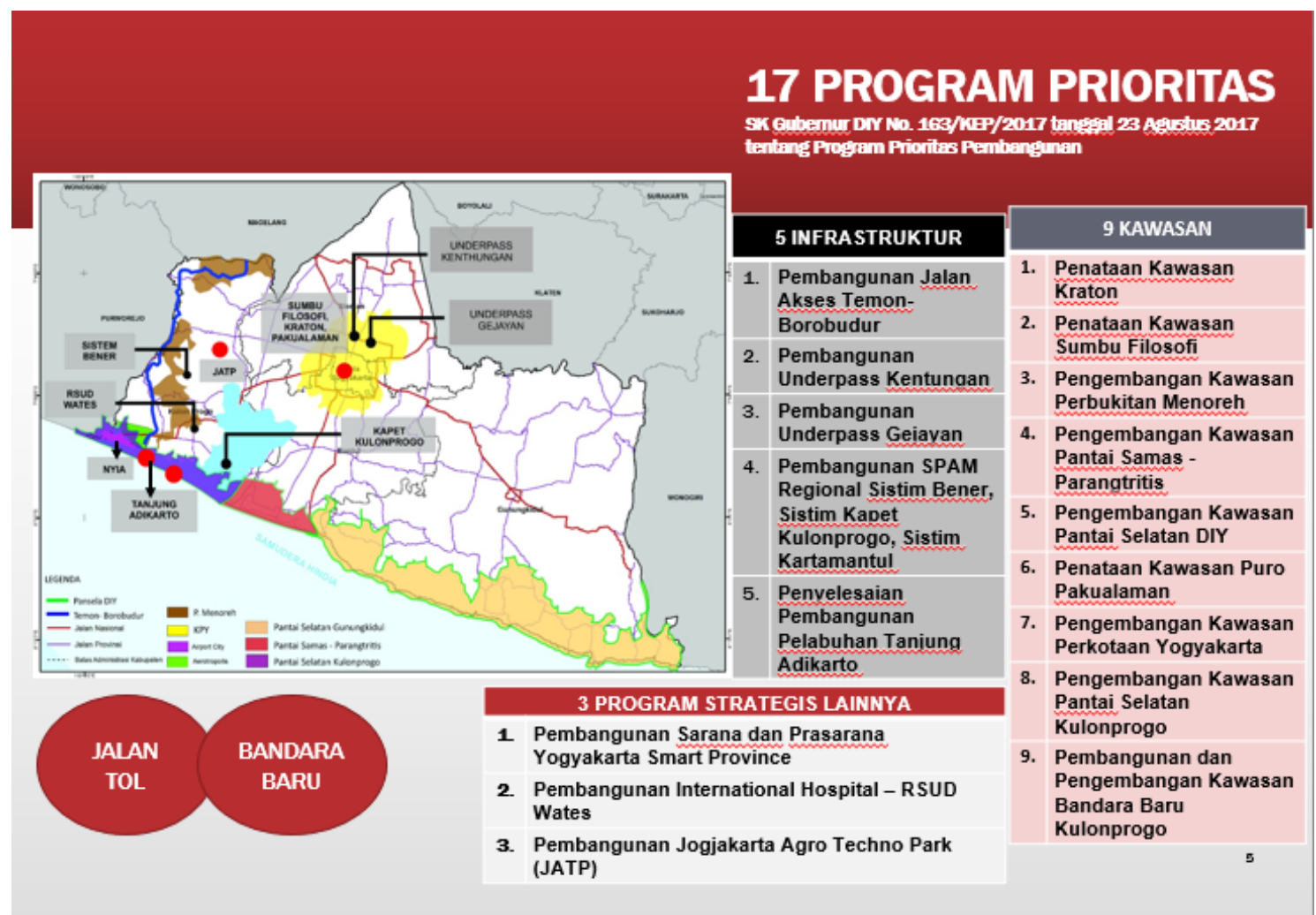

Ada 17 program inilah yang menjadi inti bagaimana sirkuit sekunder menjadi penyokong sirkuit primer.

Pada tahun 2017, Kabupaten Kulon Progo menjadi kabupaten dengan angka kemiskinan tertinggi se-DIY. Tingkat kemiskinan di Kabupaten Kulon Progo pada tahun 2017 mencapai 20,03\%. Sementara, beberapa lainnya seperti Kabupaten Bantul 14,07\%, Kabupaten Sleman 8,13\%, Kabupaten Gunung Kidul 18,65\%, dan Kota Yogyakarta sebesar 7,64\%. Meski demikian, garis kemiskinan di Kabupaten Kulon Progo lebih tinggi dari Kabupaten Gunung kidul dengan sebesar 312.403,00 Rupiah/Kap/Bulan (BPS, 2017). Niatnya, pembangunan YIA bagi Hasto dapat menggenjot perekonomian warga dan menurunkan angka kemiskinan. Meski yang dibayangkan harus mengikhlaskan petani dan lahan pertanian.

"Pembangunan YIA bukan hanya sebab-sebab pragmatis saja- semisal, kelebihan kapasitas bandara Adisutjipto - melainkan juga didasari oleh upaya displacement 
dalam mengatasi krisis akumulasi berlebih akibat pembangunan di Yogyakarta. Seperti umum diketahui, pembangunan di Yogyakarta mencapai tingkat pertumbuhan yang eksplosif selama dekade terakhir - dibuktikan dengan tren PDRB yang meningkat tiga kali lipatnya. Meski demikian, tingkat ketimpangan Yogyakarta yang sangat tinggi (per September 2016, rasio Gini di Yogyakarta mencapai angka 0,43 - lebih besar dari rerata rasio Gini nasional) menunjukkan bahwa mayoritas pertumbuhan ekonomi tersebut hanya dinikmati oleh kelas pemilik modal. Hal serupa juga ditunjukkan dari minimnya pengeluaran seperlima penduduk di segmen termiskin, yang jumlahnya hanya sebesar 5,7 persen dari total pengeluaran penduduk Yogyakarta." (Darmawi, 2004)

Seperti yang telah dijelaskan di atas, PT. Angkasa Pura I dan Negara berusaha memaksakan artian "Sejahtera" kepada warga masyarakat. Kesejahteraan yang dimaksud adalah penyerapan tenaga kerja dan penciptaan "kelas buruh" baik sektor informal ataupun sektor formal. Serta ekonomi yang berbasis pariwisata dan berbagai ekonomi "lokal" disekitarnya. Penciptaan kelas pekerja "rentan" atau industrial reserve army bertujuan untuk sewaktu-waktu mengganti tenaga kerja industri yang labor powernya tidak dapat memenuhi kebutuhan industri lagi (Marx, 1991)

Ia juga menandakan tenaga kerja yang tidak terserap oleh akumulasi produktif kapital. Bahkan dalam proses proletarianisasi atau akumulasi primitif -pemisahan manusia dalam konteks ini petani dengan tanah sebagai alat produksinya- tidak serta merta petani akan langsung menjadi proletariat aktif yang terlibat dalam akumulasi produktif kapital (Habibi, 2016). Mereka diombang-ambingkan dalam keadaan yang tidak tentu dan menjadi cadangan bagi proletariat aktif. Biasanya, produktivitas mereka lebih rendah daripada proletariat aktif di sektor formal yang terlibat dalam relasi produksi kapitalisme.

Bagi Marx, istilah yang tepat adalah proletarianisasi. Namun, beberapa tokoh agraria seperti Araghi (1995) dalam "Global Depeasantization, 1945-1990”, istilah untuk menunjukkan gejala berkurangnya petani adalah depeasantization. Istilah tersebut menunjukkan bagaimana berbagai kekuatan ekonomi politik bekerja pada tingkat global hingga tingkat paling kecil sekali pun sehingga menghasilkan kecenderungan pengurangan jumlah kelas petani di pedesaan (F. Araghi, 1995). Selanjutnya, terdapat kecenderungan untuk berpikir "seperti kota" yang meninggalkan pertanian untuk meningkatkan perekonomian. Artinya, kapitalisme akan mengubah tanah, tenaga kerja, dan kekayaan menjadi komoditi-komoditi dan hal ini hanyalah sebuah formula ringkas untuk melikuidasi lembaga-lembaga sosial dan kebudayaan yang dinilai menghambat (Setiawan, 2008). Begitu pula dengan gerakan rakyat yang menentangnya.

Buat Marx (1991), "Industrial Reserve Army" atau "relative surplus population" (RSP) terdiri dari kaum pekerja yang tersedia dalam jumlah berlebihan untuk keperluan akumulasi modal pada tingkat perkembangan perekonomian kapitalis tertentu. Corak produksi kapitalis membutuhkan ketersediaan tenaga kerja yang dipasok dengan mengekstraknya dari apa yang disebut buruh bebas yang tidak memiliki sarana subsistensi 
lain selain tenaga kerja mereka (Habibi \& Juliawan, 2018). Oleh karenanya, manusia hanya dipandang sebatas seberapa kuat labor power-nya untuk memproduksi sejumlah komoditas tertentu, bahkan tenaga kerja itu sendiri merupakan komoditas. Pada tahap tertentu akhirnya manusia dihisap hingga yang tersedia hanya raganya untuk dijual. Penghisapan manusia atas manusia menjadi syarat wajib bagi mode produksi kapitalisme

Secara singkat, mereka juga diperlukan sebagai kendala terhadap kenaikan upah pada segmen tenaga kerja yang justru terlibat dalam proses ekonomi. Mereka menjadi keadaan kontradiksi dalam kapitalisme karena jumlah mereka yang makin membengkak antara lain dengan peningkatan dan inovasi teknologi produksi yang menghemat pemakaian tenaga kerja manusia (Habibi, 2016). Namun, disisi lain mereka diperlukan untuk cadangan tenaga kerja bagi korporasi-korporasi. Beberapa diantaranya menjadi proletariat, beberapa yang lain menjadi "semi-proletar". Meski demikian, pekerja rentan juga mengindikasikan tidak adanya kepastian upah dan jaminan keselamatan kerja

Dengan melemparkan ke mekanisme pasar bebas tenaga kerja, masyarakat sekitar akan berkompetisi dengan tenaga kerja lainnya.

"...Meski sudah dibekali keterampilan dengan pelatihan, Angkasa Pura I tak bisa menjamin bahwa semua warga terdampak dan tergusur akan bisa bekerja di bandara. Dengan logika pasar tenaga kerja yang galibnya menuntut upah semurah mungkin, peluang warga di areal terdampak bisa bekerja di bandara bergantung pada 'seberapa kesiapan warga itu sendiri,' ujar Agus Pandu Purnama, Manajer Umum Angkasa Pura I Yogyakarta, kepada Tirto pada 17 Agustus lalu....Jadi pertarungannya terbuka. Jadi kalau Angkasa Pura I [hanya] berupaya warga di sini kami latih, kami siapkan.” (Kresna, 2018).

Tergantung tentang bagaimana mekanisme pasar bebas tenaga kerja akan menyerap hal tenaga kerja yang dibutuhkan. Perkara berpindah pekerjaan yang selama ini turun menurun menjadi petani dan ganti menjadi pekerja yang bukan tani lagi bukan hal yang mudah. PT. Angkasa Pura I dan negara mengimajinasikan kesejahteraan dengan adanya bandara yang memicu geliat pertumbuhan ekonomi melalui industri, industri ekonomi kreatif, pariwisata, dan sebagainya.

Surplus-surplus tenaga kerja akan ditempatkan dilevel industri kreatif apabila tidak bisa bersaing dengan tenaga kerja lain di pasar tenaga kerja formal. Penetrasi keruangan dan kawasan menjadi konsekuensi logis pembukaan bandara. Penetrasipenetrasi ini digunakan untuk membuka ekspansi ruang atau kawasan baru untuk akumulasi kapital dan ruang untuk menyediakan cadangan tenaga kerja. Alhasil, penetrasi tenaga kerja digunakan untuk memenuhi kebutuhan-kebutuhan lahan-lahan baru akumulasi kapital.

Estimasinya, sekitar 3.000 tenaga kerja dibutuhkan untuk beroperasinya bandara dengan rentan usia antara 17 sampai 35 tahun (Putera, 2018). Artinya, tenaga kerja yang memenuhi standar PT. Angkasa Pura I akan dipekerjakan di bandara dengan sistem pasar bebas tenaga kerja. Sementara, mereka yang terlempar -yang artinya tidak 
memenuhi- akan ditempatkan pada sektor-sektor informal. Mereka pun telah dilatih untuk menjadi sektor-sektor informal apabila terlempar dari kriteria PT. Angkasa Pura I. Pelatihan tersebut sebanyak 8 paket, terdiri teknisi telepon seluler, mekanik yunior mobil, menjahit, finishing kayu teknik semprot, teknisi lemari pendingin (show case) dan sepeda motor injeksi, serta boga 2 paket (Widiyanto, 2018)

Estimasi tersebut sangat jauh apabila disandingkan dengan data riset JDA yang menyatakan 11.501 jiwa penduduk di Desa Temon, Desa Glagah, Desa Sindutan, Desa Kebonrejo, Desa Palihan, dan Desa Jangkaran terancam lantaran bekerja sebagai petani, buruh, dan nelayan (JDA, 2017). Data tersebut belum termasuk data pekerja yang tinggal di luar keenam desa dan bekerja di keenam desa itu.

Ruang-ruang dikondisikan sedemikian rupa menjadi representasi ruang yang dianggap mampu untuk memberikan akumulasi kapital yang lebih. Ruang-ruang tenaga kerja yang dapat menopang kerja-kerja YIA dapat dikategorikan sebagai sirkuit sekunder yang dalam bentuk konkrit kawasan industri (industri informal) dan perumahan. YIA pun dalam ekspansi akumulasi kapital yang lebih besar, ia menjadi sirkuit sekunder. Primernya, tetap pada sektor pariwisata.

Gambar 1 Rencana Pola Ruang Kawasan Budidaya

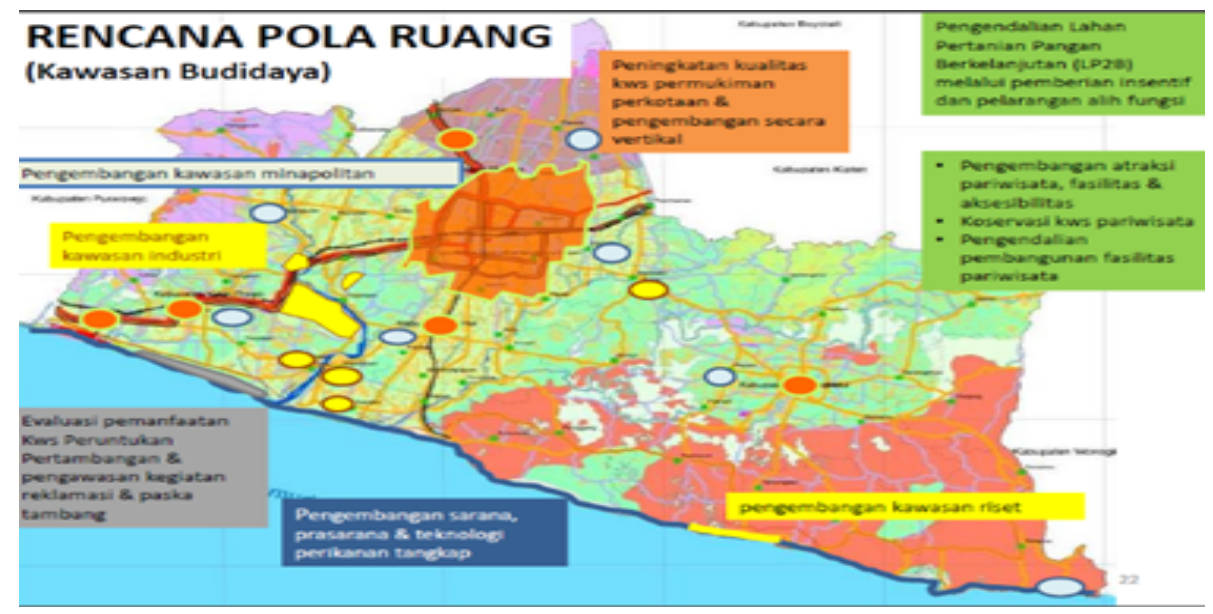

Jika dilihat lebih rinci, maka pengorganisiran ruang untuk kota bandara menjadi;

Gambar 2 Pola tata ruang kota bandara

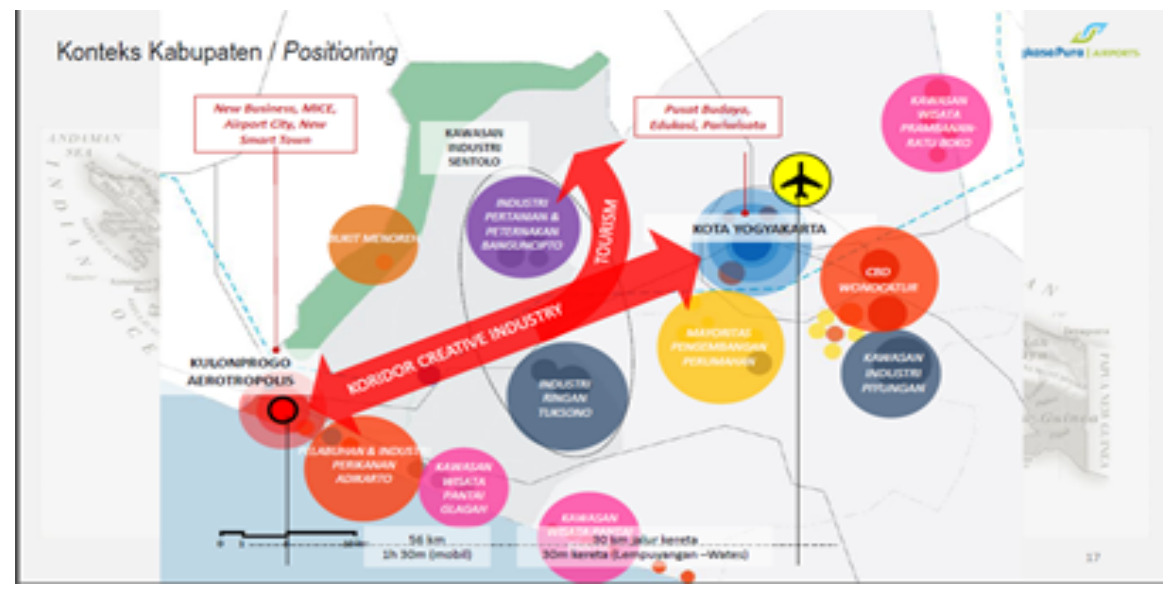


Kawasan-kawasan yang dulunya pertanian menjadi ruang-ruang akumulasi kapital "alternatif" dan menjadi lumbung bagi tenaga kerja. Ruang akumulasi kapital "alternatif" ini diranahkonkritkan menjadi industri-industri non-formal seperti tukang jahit, toko oleh-oleh, dan lainnya. Dengan adanya berbagai kerentanan kerja, mereka harus bersaing dengan tenaga kerja lainnya untuk dapat bekerja di YIA. Rakyat yang telah nyaman menjadi was-was apabila tidak bisa bekerja, maka sudah sewajarnya mereka menolak.

Pembayangan tentang kelas pekerja pun direduksi hanya sebatas tenaga kerja informal yang siap untuk menunggu terserap oleh sektor-sektor formal. Kerja-kerja informal dianggap efektif oleh pemerintah untuk mendorong perekonomian dan dinilai "setara" dengan kerja-kerja sektor formal. Namun, dibalik itu semua terdapat penghisapan manusia atas manusia. Terdapat ketidakstabilan situasi pekerjaan yang terdiri dari kondisi pekerja, upah yang tidak tentu, dan jam kerja. Mereka mungkin terlibat dalam pasar komoditas yang besar -ekspor dan impor komoditas. Namun, mereka juga terlibat dalam perdagangan kecil (penjaja atau penjual).

Dengan kata lain, mereka akan diubah menjadi Surplus Populasi Relatif. Mereka terdiri dari pekerja di sektor agraria di pedesaan "Terus-menerus pada titik untuk beralih ke proletariat perkotaan atau manufaktur" (Marx, 1991). Mereka akan menjadi cadangan tenaga kerja industri yang sebenarnya mereka telah dirampas aksesnya ke tanah. Sederhananya, ketika produksi kapitalis mengambil alih pertanian mereka yang menjadi sumber mata pencaharian. Petani dengan sedikit atau tanpa tanah adalah yang paling rentan terhadap perampasan tersebut. Penetrasi tenaga kerja salah satunya adalah mereka yang telah kehilangan aksesnya terhadap tanah karena YIA. Penetrasi tenaga kerja yang lain berasal dari pasar bebas tenaga kerja untuk memperebutkan menjadi sekrup-sekrup kapital untuk memutar akumulasi YIA.

Alhasil, hilangnya perlindungan dari negara kepada buruh, persaingan terbuka antara tenaga kerja Indonesia dengan tenaga kerja asing, ketidakpastian hubungan kerja dan ketidakpastian kerja serta penurunan kesejahteraan mengancam mereka. Disisi lain, secara massif terjadi gerakan penggantian status kerja dari pekerja tetap menjadi pekerja kontrak, melalui sistem outsourcing tenaga kerja. Sebagai tenaga kontrak, yang direkrut melalui perusahaan pengerah tenaga kerja (outsourced) - yang banyak muncul di pusatpusat industri sebagai bisnis yang sangat menguntungkan - buruh hanya mendapatkan upah pokok sebesar upah minimum setempat tanpa tunjangan lain. Padahal, mereka melakukan pekerjaan yang persis sama dengan buruh tetap (Tjandraningsih, 2007). 
Gambar 3 Draft Kota Bandara

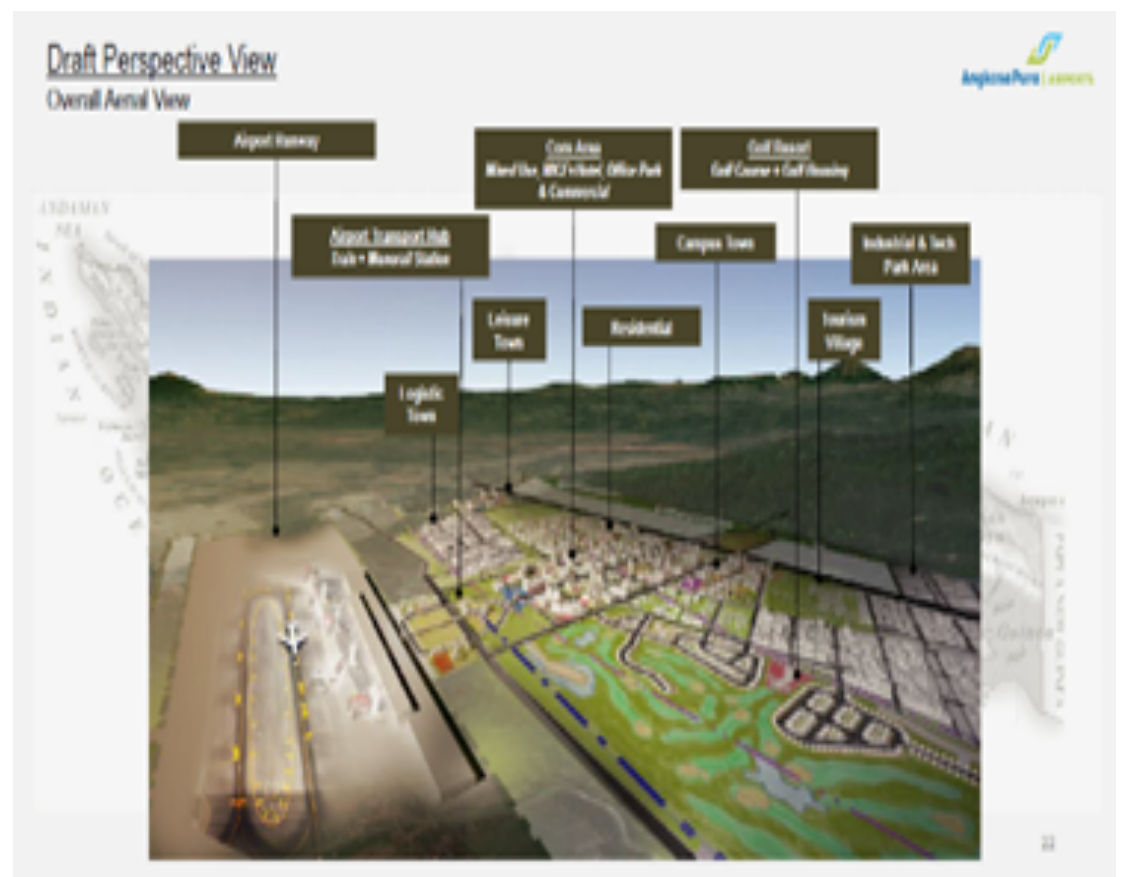

PT. Angkasa Pura I telah memperhitungkan adanya tempat tinggal bagi tenaga kerja. Selain itu, perumahan yang merembet ke desa dan menggusur pertanian juga menunjukkan fenomena urban sprawl. Ia didefinisikan sebagai proses pengembangan permukiman perumahan di daerah pinggiran dengan kepadatan penduduk yang rendah dan menyebar (Hayden, 2004). Dengan kata lain, ia bisa didefinisikan sebagai fenomena melebarnya pembangunan hingga ke daerah pinggiran kota dan menggusur daerah pertanian.

Perumahan yang akan dibangun bukan hanya bagi mereka yang bekerja untuk bandara, namun bagi mereka yang mempunyai kapital lebih untuk mendirikan perumahan. Penetrasi perumahan tersebut juga memicu liberalisasi ekonomi, meskipun wadahnya adalah "ekonomi kreatif” -yang mana akan berakhir pada pasar. Maka, liberalisasi ekonomi akan diperluas cakupannya dengan adanya bandara dan segala piranti yang akan mengikutinya. Dan pembebasan lahan (-red penggusuran) menjadi syarat wajib untuk membangun segala piranti untuk memenuhi kebutuhan hidup tenaga kerja. Kapitalisme hari ini, menggunakan infrastruktur untuk melakukan eksklusi lewat inklusi. Sejumlah tenaga kerja dikonsentrasikan pada ruang tertentu untuk kebutuhan tertentu. 
Gambar 4 Pengorganisiran ruang kluster ekonomi

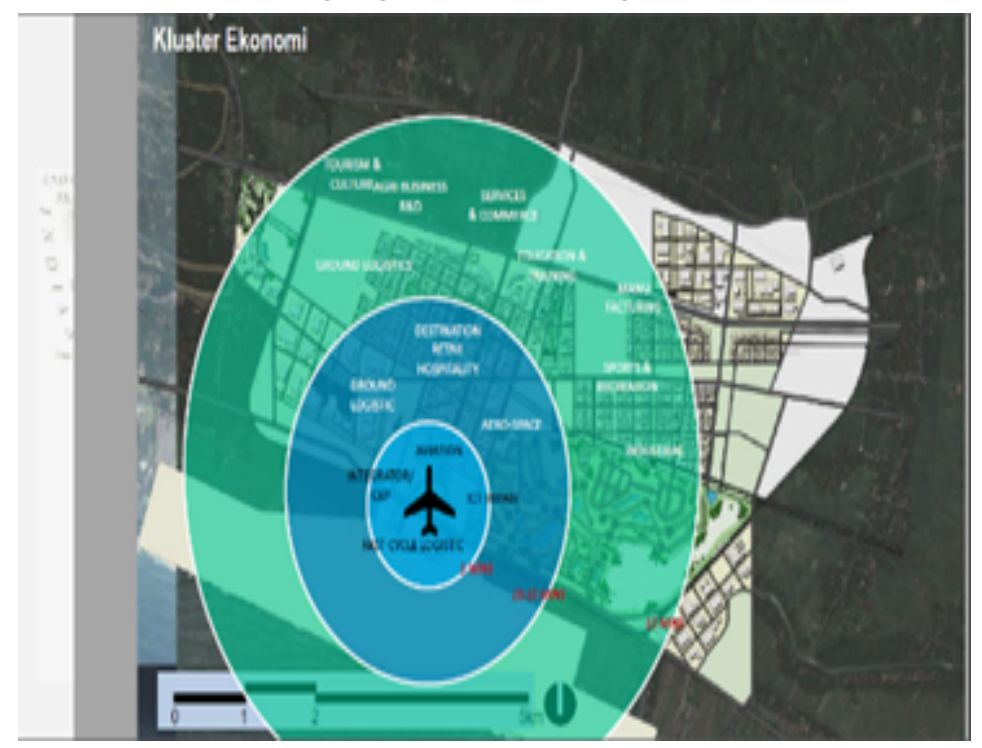

Paparan tersebut secara jelas telah menggambarkan sirkuit sekunder yang akan menopang YIA. Mulai dari logistik, tempat perawatan, industri kreatif, dan lainnya. Sementara, ruang-ruang yang dibuka untuk daerah edukasi dan pelatihan yang mana sebagai sirkuit tersier digunakan untuk meningkatkan labor power calon pekerja. Sirkuitsirkuit tersebut akan menopang sirkuit primer untuk mengakumulasikan kapitalnya. Dalam ranah yang lebih luas, akumulasi kapital lewat pariwisata. Hal tersebut menjadi wajar, karena pemerintah menjadikan pariwisata sebagai leading sector pembangunan, maka grand design pembangunan pun diusahakan mendukung sepenuhnya pembangunan pariwisata.

Mantra kapitalis paling umum adalah, "semua orang bisa kaya jika mereka bekerja keras" mengandung kesesatan berpikir. Hanya ada begitu banyak ruang di atas. Untuk menghasilkan uang, manusia harus melepaskannya dari orang lain. Dapat dilakukan melalui penjualan barang, perpajakan atau cara lain. Tetapi, hal tersebut berarti berarti bahwa yang kaya tidak akan ada tanpa yang miskin. Bagaimanapun manusia melihatnya, tidak akan pernah ada persamaan di bawah kapitalisme.

Pekerja miskin tidak hanya telah mengalami krisis reproduksi yang intensif, tetapi juga fragmentasi karena mereka dipaksa untuk bergerak melintasi ruang pedesaan dan perkotaan. Diombang-ambingkan antara tenaga kerja tidak tetap yang "berbahaya", produksi komoditas kecil, dan bentuk-bentuk non-pertanian informal untuk bertahan hidup -sebuah kompleksitas tentang "kapitalisme mikro tanpa henti" dari slum area (daerah kumuh) (Davis, 2006).

\section{Arus Barang dan Arus Manusia}

"Yogyakarta tidak bisa hidup tanpa pariwisata. Ia jalan satu-satunya," begitu jika saya parafrase kalimat yang dilontarkan oleh Anthonius Tony Prasetiantono yang 
juga sebagai Kepala Pusat Studi Ekonomi dan Kebijakan Publik UGM. Pariwisata menjadi tumpuan ekonomi bagi Yogyakarta, selain akan didukung dengan rencana dibangunnya pelabuhan di pesisir pantai Kulonprogo pada tahun 2019 (Murdaningsih, 2018). Untuk memenuhi kebutuhan pariwisata, pembangunan jalur untuk barang dan manusia.

Akibat dari kompresi ruang-waktu untuk mengekspansikan kapital (-red memangkas waktu distribusi), mendorong penemuan teknologi seperti rel kereta api dan jalan tol untuk mentransformasi skala geografis. Transformasi tersebut memungkinkan hambatan menjadi lebih ringkas dan lancar untuk sirkulasi dan akumulasi kapital. Hari ini, rezim infrastruktur yang dibangun memfokuskan diri pada hal tersebut. Pemangkasan waktu distribusi untuk akumulasi dan sirkulasi kapital. Itulah jawaban Kapitalisme untuk menghadapi krisis yang terjadi padanya. Ruang-ruang geografi bagi kerja kapital secara temporal harus diperlebar hingga menjangkau dan menyerap teritorial-teritorial baru untuk masuk ke dalam proses kerja kapital (Ridho, 2018).

Arus manusia yang saya maksud tidak sebatas penetrasi tenaga kerja yang datang ke daerah sekitar YIA. Namun, arus manusia yang dimaksud juga mencakup wisatawan atau pun orang-orang yang berkeperluan untuk menunggangi pesawat. Untuk mendukung arus manusia yang akan melintas, maka pembuatan jalan tol dan rel kereta api menjadi pokok pertarungan utama. Mengapa? Karena disana lah pertarungan rakyat menjadi objek pembangunan atau menjadi subjek emansipatif pembangunan. Pertarungan tersebut akan

Pembuatan jalan tol akan menghubungkan Yogyakarta-Bawen. Sementara, untuk internal Yogyakarta, akan dibangun rel kereta api. Jika dilihat pada rancangan pembangunan, maka akan didapat:

Gambar 5 Rencana struktur ruang sistem jaringan transportasi perkeretaapian

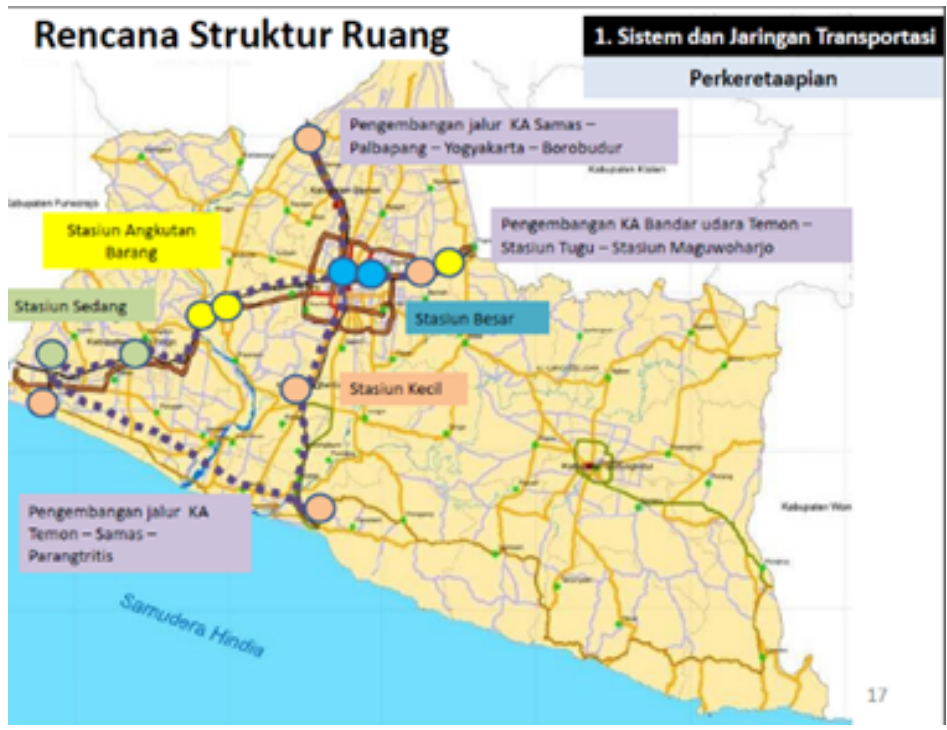

Dari gambar di atas, terdapat rencana untuk mengembangkan jalur KA TemonSamas-Parangtritis, Pengembangan KA Bandar udara Temon-Stasiun Tugu-Stasiun Maguwoharjo, dan pengembangan KA Samas-Palbapang-Yogyakarta-Borobudur. 
Pengembangan tersebut juga diikuti dengan pengembangan stasiun sedang, stasiun angkutan barang, stasiun kecil, dan stasiun besar. Untuk memenuhi kebutuhan melayani arus barang, maka stasiun angkutan barang akan menjadi pilihan.

Sementara, jalan tol Yogyakarta-Bawen pada desember 2018 telah berada dalam tahap pembuatan trase dan penetapan lokasi, serta pembebasan lahan (Ose, 2018). Pemerintah Kabupaten Sleman sebagai wilayah yang menjadi wilayah poros penyambung proyek sudah mengirim tim Bappeda kabupaten Sleman untuk berkoordinasi dengan pemerintah provinsi Jateng.

Selain jalan tol Yogyakarta-Bawen, jalan tol Yogyakarta-Solo juga akan dibangun. Proyek tersebut diperkirakan membutuhkan nilai investasi sebesar Rp. 19 Triliun. Nilai tersebut dianggap sebanding, karena sepanjang 15 kilometer jalannya akan dibuat melayang. PT. Adhi Karya diketahui telah mengajukan prakarsa proyek tersebut ke Kementerian PUPR. Sementara, sampai pada tanggal 9 Januari, proyek tersebut masih dalam proses persiapan lelang.

"Hotel, guest house sampai rumah warga akan menjadi tempat menginap para tamu. Artinya memiliki dampak ekonomi bagi masyarakat. Kita genjot pariwisata, kita datangkan banyak orang. Ada yang bilang dolar naik aduh gawat, ya justru kita gairahkan pariwisata," terang Ganjar Pranowo (Ose, 2018).

Dari pernyataan di atas, jalan tol akan membuka peluang perampasan lahan yang akan lebih massif. Pembuatan jalan tol pada akhirnya dari "memfasilitasi bisnis" menjadi "bisnis itu sendiri". Dengan dalih memperlancar pariwisata, maka pembangunan hotel dan berbagai macam masalah di dalamnya -krisis air- menjadi konsekuensi logis. Pada akhirnya, rakyat hanya menjadi objek pembangunan ekonomi neoliberal yang basisnya untuk mengabdi pada pariwisata dan sektor informal. Awalnya jalan tol ditujukan untuk kompresi ruang-waktu, namun berjalan dan menjadi ruang akumulasi kapital itu sendiri. Pembuatan imajinasi atas kota pun "ditentukan" oleh penguasa yang memaksa rakyatnya untuk mengabdi pada kapital.

Menurut laporan dari Mahmud (2019) berjudul "Proyek Jalan Tol Solo-JogjaBawen-Cilacap", rute jalan tol akan melewati 9 kecamatan dan 21 desa di Sleman. Dengan rincian, Tol Yogyakarta-Solo melewati 6 kecamatan dan 14 desa, meliputi: Prambanan, Kalasan, Depok, Ngaglik, Gamping, dan Melati. Sementara, YogyakartaBawen meliputi: Mlati, Seyegan, Tempel. Data yang berhasil saya himpun dari seminar lalala, Trase Yogyakarta (Sleman)-Solo melalui: Prambanan (Desa Bokoharjo), Kecamatan Kalasan (Desa Tamanmartani, Desa Selomartani, Desa Tirtomartani, Desa Purwomartani), Kecamatan Depok (Desa Maguwoharjo, Desa Condongcatur dan desa Caturtunggal). Tiga lainnya berada di Kecamatan Ngaglik (Desa Sariharjo), Kecamatan Mlati (Desa Sinduadi, Desa Sendangadi, Desa Tlogoadi, dan Desa Tirtonadi), terakhir Kecamatan Gamping (Desa Trihanggo).

Sementara, trase tol Yogyakarta (Sleman)-Bawen berada di Kecamatan Tempel (Desa Banyurejo), Kecamatan Seyegan (Desa Mergokaton, Desa Mergodadi, dan Desa 
Margomulyo). Sementara, tiga lainnya berada di Kecamatan Godean (Desa Sidomulyo), Kecamatan Mlati (Desa Tirtoadi, dan Desa Tlogoadi), dan Kecamatan Gamping (Desa Trihanggo).

Seiring berjalannya pembangunan kota bandara, akan disertai trase jalan tol Kulon Progo. Terdapat 16 desa yang akan menjadi sasaran dan 7 diantaranya menjadi sasaran tol melayang. Sementara, 9 lainnya akan berada di atas tanah. 7 daerah yang akan menjadi sasaran tol melayang, yaitu: Temon Wetan, Kaligintung, Kulur, Hargorejo, Karangsari, Wates, dan Sendangsari. Sementara, 9 daerah yang menjadi trase jalan tol di atas tanah adalah Hargomulyo, Karang Wuluh, Janten, Kebonrejo, Remon Kulon, Pengasih, Kaliagung, Donomulyo, dan Banguncipto. Sementara, jalan tol SoloBawen-Yogyakarta akan dilengkapi dengan enam pintu gerbang (keluar-masuk). Enam pintu tersebut tersebar di Maguwoharjo (Lottemart), Simpang UPN, Simpang Monjali, Trihanggo (Westlake), juntion toll (simpang susun) Seyegan, dan junction toll Bligo (Magelang).

Berikut adalah gambaran tentang trase jalan tol:

Gambar 2 diambil dari Presentasi Cholid Mahmud di UG UGM pada 11 November 2019

\section{Rencana Trase Jalan Tol Yogya Solo}

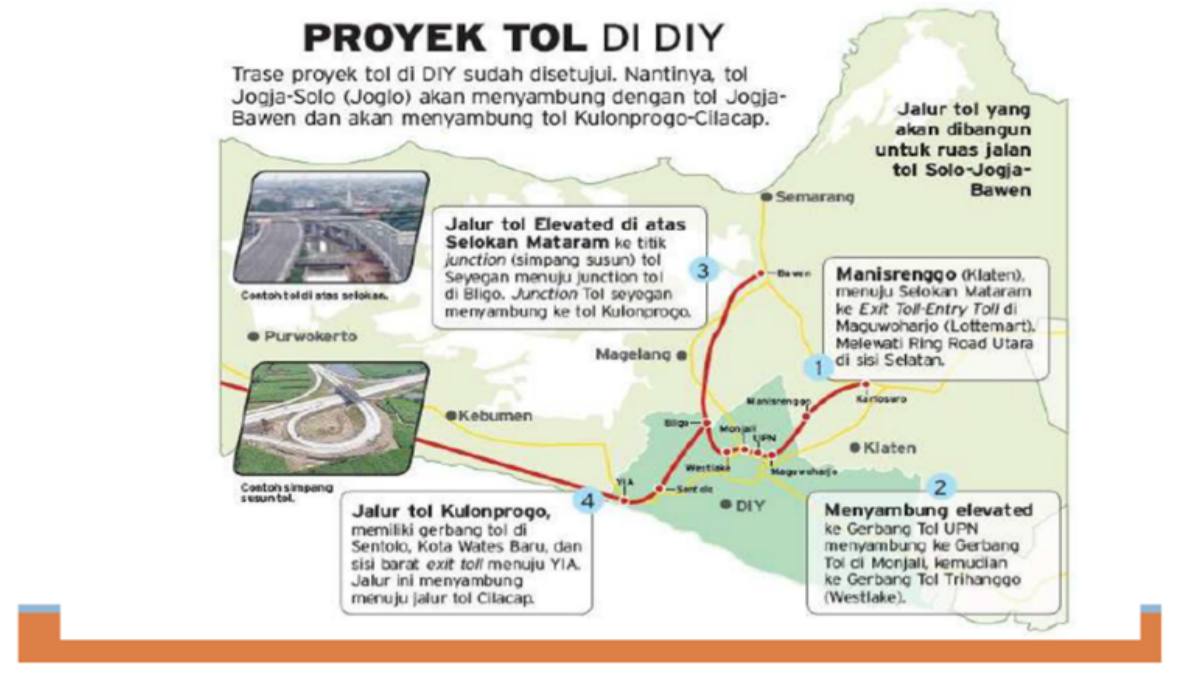

Selain itu, untuk mendukung arus barang dan arus manusia lewat udara dan laut, maka: 
Gambar 6 Rencana Struktur Ruang Sistem dan Jaringan Transportasi Laut dan Udara

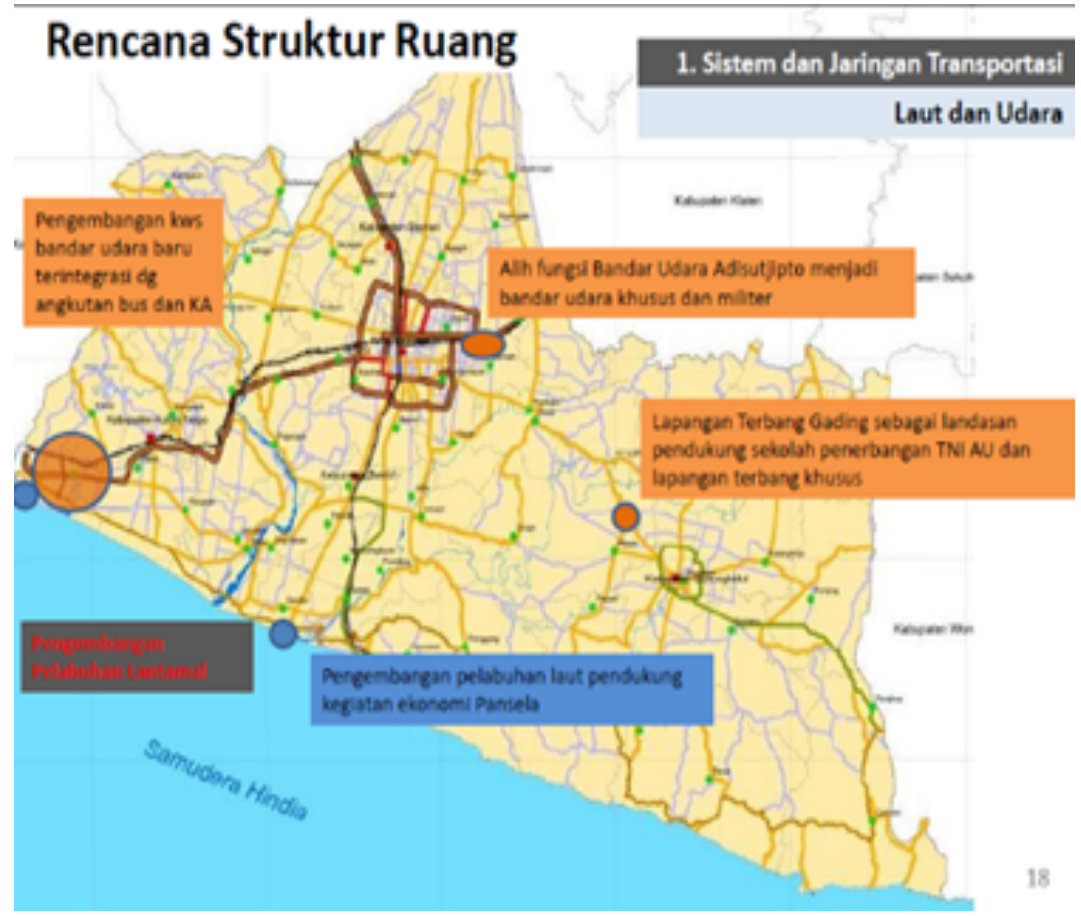

Dalam gambar tersebut terdapat pengembangan pelabuhan Lantamal dan pengembangan pelabuhan laut pendukung kegiatan ekonomi Pantai Selatan (Pansela). Jalur ekonomi Pansela digadang-gadang akan memacu sektor ekonomi pertanian, ekonomi industri, ekonomi kreatif, pariwisata, hingga UMKM. Dari sisi pertanian, keberadaan jalur Pansela itu akan mempermudah akses distribusi hasil panen, sehingga membuka peluang bagi pasar besar untuk mengambil langsung kepada para petani meskipun tengkulak akan bermain (Rismawan, 2018).

Sirkuit-sirkuit sekunder tersebut (dalam konteks sub-bab ini rel kereta api, jalan tol, bahkan bandar itu sendiri dan pelabuhan) menghubungkan secara langsung menuju sirkuit primer. Dengan didukung oleh sirkuit sekunder dan sirkuit primer, maka akumulasi kapital akan terjaga dengan stabil. Kestabilan akumulasi kapital dalam konteks pariwisata dilihat dari arus barang dan arus manusia (pariwisatawan atau pun pekerja) yang berada dalam kondisi aman. Pengaturan kondisi tersebut salah satunya dengan melakukan hegemoni bahwa "industri kreatif" ada untuk mensejahterakan rakyat. Lahan pertanian warga dirampas dengan dalih modernitas dan pembangunan.

Mazhab pembangunanisme yang berkembang masif sejak Orde $\mathrm{Ba}(\mathrm{r}) \mathrm{u}$ direproduksi dengan ukuran ada atau tidaknya gedung bertingkat, jalan lebar beraspal, hotel mewah, padatnya jumlah mobil dan gemerlapnya lampu pertokoan. Sekarang, ukurannya ditambah lagi dengan gaya hidup instan dan serba cepat (Haekal, 2017). Hal tersebut merupakan komoditas. Komoditas merupakan produk kerja manusia, tetapi komoditas bisa terpisah dari kebutuhan dan tujuan pembuatnya. 
Di dalam kapitalisme maju, kepercayaan ini berubah menjadi kenyataan karena objek-objek dan pasarnya juga menjadi fenomena nyata dan independen. Ketergantungan tersebut sebagai fetisisme komoditi. Fetisisme komoditi yang dimaksud bukanlah dalam artian Freud yang memasukkan unsur seksualitas, akan tetapi Marx merujuk pada sesuatu yang dibuat sendiri dan disembah seolah-olah ia adalah dewa (Ritzer, G. \& Goodman, 2013). Istilah fetisisme komoditi menjadi cocok untuk pembangunan.

Infrastruktur pada akhirnya, menjadi hal yang sangat vital bagi penguasaan ekonomi. Menguasai infrastruktur, berarti menguasai sirkulasi dan koneksi di dalam ekonomi. Proses pengamanan koneksi dan sirkulasi ini karena vital, bisa muncul secara brutal. Penggunaan cara-cara penggusuran paksa tanpa mengindahkan hukum, penumpasan perlawanan serikat pekerja, bahkan tindakan represif aparat menjadi pilihan praktis bagi pola pikir ini. Inilah paradigma pengorganisasian kapital dan akumulasinya yang sekarang.

Hal-hal di atas, apabila dirangkum menjadi:

"Pertama, promethean, penguasaan tanpa batas atas kekuatan materiil dari alam semesta untuk dimanfaatkan sebesar-besarnya bagi kepentingan manusia . Kedua, productiviste, bukan hanya karena sistem ini memproduksi barang dan jasa untuk kepentingan manusia, akan tetapi juga meletakkan proses teknologi tanpa batas, guna melayani pertambahan terus menerus dari berbagai jumlah barang. Masyarakat seolah-olah dihukum untuk selalu memproduksi dan mengonsumsinya, melalui kenaikan jumlah produksi dan konsumsi yang tidak ada habisnya. Ketiga, expantionisme, yang secara mutlak menuntut keuntungan pada sumber daya, memobilisasi tanpa batas keuntungan faktor-faktor produksi. Sehingga, dalam kaitannya dengan ciri ketiga, cara yang paling ampuh adalah dengan melakukan imperialisme, kolonialisme atau promosi melalui papan reklame. Keempat, marchan, sistem ekonomi dunia berjalan dengan dua cara perdagangan internasional dan pertumbuhan ekonomi nasional. Keempat ciri tersebut sepadan dengan proses akumulasi kapital mondial, yaitu dasar utama dari eksploitasi model lama dan mutakhir." (Prasetyo, 2015).

Konflik keruangan, merupakan sebuah problem hasil dari pemaknaan terhadap ruang sebagai arena produksi. Kemudian ruang tersebut dikonsepsikan sesuai dengan kepentingan kapitalis dan pemerintah. Karena, ruang merupakan lokus produksi atau tempat di mana terjadi proses produksi untuk akumulasi keuntungan. Ruang merupakan sebuah prasyarat bagi kapitalisme dalam upaya penguasaan perekonomian. Oleh karenanya, dibutuhkan kebijakan dari penguasa teritorial atas peguasaan ruang.

Sebagai wong cilik, tanpa organisasi dan kesadaran politik yang jelas rakyat tak berdaya jika harus melawan penguasa. Dalam sekian banyak narasi konflik, hanya sedikit kemenangan yang berpihak pada rakyat - kemenangan yang lain jelas berpihak pada pemilik modal. Negara yang seharusnya melindungi rakyat kecil justru lebih memihak pada pemodal. Ketika negara telah tunduk pada pemodal, ia seakan menjadi Tuhan 
baru. Berbagai kebijakan diterapkan sebagai bentuk penghambaan terhadapnya. Bahkan, pemerintah berani memangkas segala hal yang dapat menghalangi bekerjanya mekanisme pasar. Hal tersebut berdampak pada hubungan negara dengan rakyatnya. Dominasi negara muncul karena negara mempunyai kuasa yang lebih, baik melalui birokrasi maupun melalui monopoli kekerasan yang terwujud dalam lembaga militer dan polisi (Haekal, 2017).

Maka, penggusuran adalah harga yang harus dibayar agar perputaran kapital di Yogyakarta bisa berjalan. Oleh karenanya, hal-hal tersebut mencerminkan bagaimana pembangunan di desa dilakukan dengan cara pikir "orang kota", dengan mengubah desa menjadi kota. Bisa pula dikatakan "orang yang lebih beradab" -karena bersentuhan dengan modal yang lebih- memandang orang desa.

\section{Simpulan}

Melalui pembacaan keruangan Harvey dan Lefebvre, pembangunan YIA akan menggusur lahan yang lebih massif lagi. Tidak hanya berpengaruh secara keruangan, namun pembangunan YIA juga berpengaruh terhadap kehidupan di atasnya. Melalui pembayangan kelas pekerja rentan, YIA melalukan eksklusi dengan inklusi. Maksudnya, rakyat dieksklusi dari hidupnya sebagai petani baik secara keruangan maupun penghidupan. Namun, ia diinklusi pada ruang tertentu untuk difokuskan menjadi tenaga kerja maupun tenaga kerja cadangan untuk akumulasi aktif kapital. Sebagai pemutar kapital, pariwisata mengandaikan tetesan yang lebih merata kepada masyarakat. Dengan menjual keindahan alam yang ada di Kulon Progo, rakyat diharapkan menjadi pekerja informal dengan menjual oleh-oleh khas, dan lainnya demi mendongkrak angka kesejahteraan. Pada taraf berikutnya, terdapat paradoks yang diciptakan oleh negara. Pembangunan infrastruktur lanjutan setelah YIA, dipandang sebagai kompresi ruangwaktu yang menciptakan lapangan kerja informal. Namun, pekerja informal juga dimungkinkan untuk kehilangan mata pencaharian karena infrastruktur. Sebagai sirkuit sekunder, YIA menghubungkan dengan sirkuit primer -pariwisata. Namun, sirkuit sekunder tersebut tidak hanya berhenti di YIA. Infrastruktur lanjutan pasca YIA terbangun akan menjadi proyek strategis menggusur warga dari tanahnya. Jalan tol hanya lah salah satu contoh bagaimana tanah akan dipisahkan dari warga untuk memenuhi kebutuhan kapital lewat pariwisata.

\section{Ucapan Terima Kasih}

Terima kasih kepada semua pihak yang terlibat dalam pendalaman diskusi terkait dengan penulisan artikel.

\section{Pendanaan}

Penulis tidak menerima bantuan pembiayaan untuk penelitian, kepenulisan (authorship), dan publikasi dari pihak manapun 


\section{Daftar Pustaka}

Araghi, F. (1995). Global Depeasantization 1945-1990. Sociological Quarterly, 36(337-368).

Araghi, F. A. (1995). Global Depeasantization, 1945-1990. The Sociological Quarterly, 36(2), 337-368.

BPS. (2017). Data Kemiskinan. Retrieved February 2, 2020, from http://bappeda.jogjaprov.go.id/dataku/data_dasar/index/383kemiskinan?id_skpd=29

Cahyono, S. (2018). Pengosongan Lahan NYIA Sasar Tanaman Palawija. Retrieved February 2, 2020, from https://www.jawapos.com/jpg-today/28/ 06/2018/pengosongan-lahan-nyia-sasar-tanaman-palawija

Darmawi, H. (2004). Manajemen Resiko. 2004: Bumi Aksara.

Davis, M. (2006). Planet of Slums. London: Verso.

Dephub. (2016). Materi Paparan Angkasa Pura. Retrieved February 2, 2020, from http://dephub.go.id/public/files/uploads/posts/posts/postbody/Materi_Pa paran_AngkasaPura.pdf

DIY, A. P. d. P. S. (2017). Bappeda Provinsi Yogyakarta. Retrieved February 2, 2020, from http://bappeda.jogjaprov.go.id/download/download/379

Fletcher, R., \& Neves, K. (2012). Contradictions in Tourism: The Promise and Pitfalls of Ecotourism As a Manifold Capitalist Fix. Environment and Society, 3(1), 60-77.

Habibi, M. (2016). Surplus Perkerja di Kapitalisme Pinggiran: Relasi Kelas, Akumulasi, dan Proletariat Informal di Indonesia Sejak 1980an. Marjin Kiri.

Habibi, M., \& Juliawan, B. H. (2018). Creating Surplus Labour: Neo-Liberal Transformations and The Development of Relative Surplus Population in Indonesia. Fournal of Contemporary Asia, 48(4), 649-670.

Haekal, L. (2017). Kapitalisasi Hak Atas Tanah. Retrieved February 2, 2020, from https://indoprogress.com/2017/08/kapitalisasi-hak-atas-tanah/

Harvey, D. (1978). The Urban Process Under Capitalism: A Framework For Analysis. International Fournal of Urban and Regional Research, 2(1-3), 101-131.

Harvey, D. (2005). The New Imperialism. OUP Oxford.

Hayden, D. (2004). A Field Guide to Sprawl. WW Norton \& Company.

Holden, W., Nadeau, K., \& Jacobson, R. D. (2011). Exemplifying Accumulation by Dispossession: Mining and Indigenous Peoples in The Philippines. Geografiska Annaler: Series B, Human Geography, 93(2), 141-161.

JDA. (2017). Booklet Dukungan PWPP-KP. Yogyakarta: Jogja Darurat Agraria.

Kemenag. (2012). Kemendag.go.id. Retrieved February 2, 2020, from http://www.kemendag.go.id/files/pdf/2012/12/06/master-plan-20112025-id0-1354731495.pdf

Kresna, M. (2018). Untuk Bekerja di Bandara NYIA diserahkan Pada Pertarungan Terbuka. Retrieved February 2, 2020, from https://tirto.id/untuk-bekerjadi-bandara-nyia-diserahkan-pada-pertarungan-terbuka-cU5S

Levien, M. (2000). pecial Economic Zone and Accumulation by Dispossession. 
Journal of Agrarian Change, 11, 454-483.

Mahmud, C. (2019). Proyek Falan Tol Solo-Jogja-Bawen-Cilacap. Yogyakarta.

Marx, K. (1991). Capital I: A Critique of Political Economy. Moscow: Penguin Classics. Murdaningsih, D. (2018). Pelabuhan Tanjung Adikarto dibangun 2019. Retrieved

February 2, 2020, from https://www.republika.co.id/berita/nasional/ daerah/18/01/07/p26x50368-pelabuhan-tanjung-adikarto-dibangun-2019

Ose. (2018). Jalan Tol Bawen-Yogyakarta Tahap Pembuatan Trase Disusul Penetapan lokasi dan Pembebasan Lahan. Retrieved February 2, 2020, from http://jogja.tribunnews.com/2018/12/28/jalan-tol-bawen-yogyakartatahap-pembuatan-trase-disusul-penetapan-lokasi-dan-pembebasan-lahan

Pamungkas, A. S. (2016). Produksi ruang dan revolusi kaum urban menurut Henri Lefebvre. Retrieved February 2, 2020, from https://indoprogress.com/ 2016/01/produksi-ruang-dan-revolusi-kaum-urban-menurut-henrilefebvre/

Prasetyo, E. (2015). Islam Kiri Melawan Kapitalisme Modal dari Wacana Menuju Gerakan. Yogyakarta: Resist Book.

Putera, A. D. (2018). Bandara Kulon Progo Bakal Serap 3.000 Karyawan, Warga Lokal Disiapkan Jadi Pramugari Hingga Petugas Avsec. Retrieved February 2, 2020, from ttps://ekonomi.kompas.com/read/2018/01/29/063700626/ bandara-kulon-progo-bakal-serap-3.000-karyawan-warga-lokal-disiapkanjadi

Rachman, N. F. (2017). Panggilan Tanah Air. Yogyakarta: Insist Press.

Ridho, M. (2018). Melawan Rezim Infrastruktur. Makassar: Cara Baca Makasar dan Social Movement Institute.

Rismawan, I. (2018). Jalur Pansela Bangkitkan Potensi Ekonomi Baru. Retrieved February 2, 2020, from http://www.tribunnews.com/nasional/2018/ 06/14/jalur-pansela-bangkitkan-potensi-ekonomi-baru

Ritzer, G. \& Goodman, D. J. (2013). Teori Marxis dan Berbagai Ragam Teori NeoMarxian. Yogyakarta: Kreasi Wacana.

Setiawan, U. (2008). Dinamika Reforma Agraria di Indonesia Setelah Orde Baru, Dalam Dua Abad Penguasaan Tanah Pola Penguasaan Tanah Pertanian di Jawa dari Masa ke Masa. Gunawan Wiradi Dan SMP Tjondronegoro (Penyunting), Tayasan Obor Indonesia, Jakarta.

Sjamsinarsi, R. (2019). Agenda Pembangunan SDM Keinsinyuran di DIY 2020-2024. Jakarta: UGM.

Tjandraningsih, I. (2007). Fleksibilitas Kerja dan kesejahteraan Buruh. Retrieved February 2, 2020, from https://indoprogress.com/2007/09/fleksibilitaskerja-dan-kesejahteraan-buruh/

Widiyanto, D. (2018). NYIA Kesempatan Buka Lapangan Kerja. Retrieved February 2, 2020, from http://krjogja.com/web/news/read/37445/NYIA_ Kesempatan_Buka_Lapangan_Ker

\section{Tentang Penulis}

Luthfian Haekal adalah peneliti dan pegiat sosial di Social Movement Institute (SMI), Yogyakarta. 